\title{
Pemanfaatan Ekstrak Daun Kemangi (Ocimum sanctum) sebagai Repelan Lalat Rumah (Musca domestica)
}

\author{
Linda Barus ${ }^{1}$, Agus Sutopo ${ }^{2}$ \\ Jurusan Kesehatan Lingkungan, Politeknik Kesehatan Tanjung Karang, Indonesia \\ Email: linda.barus1@gmail.com
}

\begin{abstract}
Utilization of Basil (Ocimum Sanctum) Leaf Extract as a House Fly Repellent (Musca Domestica). House flies are the species that play the most role in public health problems, namely as a vector of disease transmission. Control of house flies is needed without polluting the environment. The alternative developed is the use of plants as vegetable pesticides. Basil leaves used as basil leaf extract are used as vegetable insecticides to control house flies (Musca domestica). This research is an experiment to see the ability of basil leaf extract as a bioinsecticide on the repulsion/repellency of house flies. This research is experimental and analyzed using a twoway ANOVA analysis. The study consisted of two factors, the first factor was the dose of basil leaf extract: $0 \%, 20 \%, 30 \%$, dan $40 \%$, and the second factor, the time of observation of the repelling power of house flies/repelan for 5 minutes, 10 minutes and 15 minutes. Statistical test results stated that basil leaf extract: dose $0 \%$ sig value $0,011<0,05$, dose $20 \%$ sig value $0,178>0,05$, dose $30 \%$ sig value $0,031<0,05$ and dose $40 \%$ sig value $0,007<0,05$, so that the dose of $0 \%$ has an effect for the observation time of 15 minutes, the dose of $20 \%$ does not affect the repelling/repelling power of house flies, for observations of 5, 10 and 15 minutes, the dose of $30 \%$ and the dose of $40 \%$ affects, for all time observations.
\end{abstract}

Keywords: Basil leaf extract, Musca Domestica, Vegetable insecticide

\begin{abstract}
Abstrak: Pemanfaatan Ekstrak Daun Kemangi (Ocimum Sanctum) sebagai Repelan Lalat Rumah (Musca Domestica). Lalat rumah merupakan spesies yang paling berperan dalam masalah kesehatan masyarakat, yaitu sebagai vektor penularan penyakit. Diperlukan pengendalian lalat rumah tanpa mencemari lingkungan. Alternatif yang dikembangkan adalah pemanfaatan tumbuhtumbuhan sebagai pestisida nabati. Daun kemangi yang dijadikan ekstrak daun kemangi digunakan sebagai insektisida nabati untuk mengendalikan lalat rumah (musca domestika). Penelitian ini bersifat eksperimen untuk melihat kemampuan ekstrak daun kemangi sebagai bioinsektisida nabati terhadap daya tolak/repelan lalat rumah. Penelitian ini merupakan penelitian ekperimental dan dianalisis menggunakan analisis varian dua jalur (two way anava). Penelitian terdiri dari dua faktor, faktor pertama dosis ekstrak daun kemangi: 0\%, 20\%, 30\%, dan 40\%, dan faktor kedua, waktu pengamatan daya tolak lalat rumah/repelan selama 5 menit,10 menit dan 15 menit. Hasil uji statistik menyatakan ekstrak daun kemangi: dosis $0 \%$ nilai sig $0,011<0,05$, dosis $20 \%$ nilai sig $0,178>0,05$, dosis $30 \%$ nilai sig $0,031<00,5$ dan dosis $40 \%$ nilai sig $0,007<0,05$, sehingga dosis $0 \%$ berpengaruh untuk waktu pengamatan 15 menit, dosis $20 \%$ tidak berpengaruh terhadap daya tolak/repelan lalat rumah, untuk pengamatan 5,10 dan 15 menit, dosis $30 \%$ dan dosis $40 \%$ berpengaruh terhadap daya tolak/repelan lalat rumah, untuk semua waktu pengamatan.
\end{abstract}

Kata kunci: Ekstrak daun kemangi, Musca domestica, Insektisida nabati

\section{PENDAHULUAN}

Lalat merupakan jenis serangga yang sering dijumpai dalam keseharian kita dan pada hampir semua jenis lingkungan. Lalat dapat berperan dalam proses pembusukan, sebagai predator, parasit pada serangga, sebagai pollinator, penyebab myasis dan dapat berperan sebagai vektor penyakit saluran pencernaan seperti kolera, typhus, disentri. Lalat juga dapat membawa bakteri patogen, protozoa, telur serta larva cacing (Yuriatni, 2011).

Lalat rumah (Musca domestica) merupakan vektor, yang dapat menyebarkan parasit melalui kontak dengan host tanpa disertai perkembangbiakan parasit dalam tubuh lalat. Perannya sebagai vektor mekanis, disertai dengan jumlahnya yang banyak dan hubungannya yang erat dengan lingkungan hidup manusia, maka penting untuk diwaspadai ditinjau dari sudut kesehatan manusia (Mardhotillah, 2005). 
Dilihat dari kebiasaan lalat yang menyukai tempat-tempat seperti tempat sampah, maka kotoran mudah melekat pada bulu-bulu halus yang meliputi seluruh badan dan kaki lalat yang menyebabkan mudahnya lalat mentransmisikan parasit maupun organisme lain ke manusia. Kondisi lingkungan yang kotor dan berbau dapat merupakan tempat yang sangat baik bagi pertumbuhan dan perkembangbiakan bagi lalat rumah.

Penggunaan insektisida kimia di Indonesia telah memusnahkan $55 \%$ jenis hama dan $72 \%$ agen pengendali hayati. Mengingat semakin meningkatnya kesadaran masyarakat atas dampak yang diakibatkan oleh penggunaan insektisida kimia yang dapat merusak lingkungan. Penggunaan insektisida yang kurang bijaksana (khususnya yang bersifat sintesis) sering merugikan terhadap lingkungan, termasuk pencemaran air, bahan pangan, dan terpenting dapat menimbulkan gangguan kesehatan pada manusia secara langsung atau dalam jangka waktu yang panjang. Oleh sebab itu diperlukan pengganti insektisida yang ramah lingkungan. Salah satu alternatif pilihannya adalah penggunaan insektisida hayati tumbuhan. Untuk menghindari dampak negatif penggunaan insektisida kimia, maka perlu dikembangkan cara-cara baru dalam pengendalian serangga yang aman dan efektif, yaitu pemanfaatan tanaman yang mengandung zat pestisida sebagai insektisida nabati yang diperkirakan mempunyai prospek dimasa yang akan dating

Penggunaan insektisida sintesis dapat menimbulkan beberapa efek yaitu resistensi terhadap serangga, resurjensi serangga sasaran, pencemaran lingkungan, residu insektisida. Pemanfaatan tanaman sebagai insektisida nabati cenderung meningkat karena tanaman mempunyai kandungan kimia yang sangat kompleks. Sampai saat ini, setiap komponen perlu diungkap semua dan masih perlu digali. Gerakan back to the nature atau gerakan hidup sehat dengan kembali ke alam sangat condong ke arah penggunaan tanaman sebagai bahan obat, kosmetik, atau pestisida (Kathiraysen, 2011). Tanaman yang dapat menjadi insektisida nabati adalah kemangi.

Tanaman kemangi adalah tanaman yang banyak terdapat di Indonesia, tanaman kemangi biasanya dimanfaatkan untuk sayur atau lalap sebagai pemacu selera makanan. Hasil dari penelitian fitokimia pada tanaman kemangi telah membuktikan adanya flavonoid, glikosit, asam gallic dan esternya, asam cafeic, dan minyak atsiri yang mengandung eugenol $(70,5 \%)$ sebagai komponen utama (Kusuma, 2010 dalam Ariyani 2016).

Pada penelitian Gunandini (2008), pengaruh pemberian ekstrak kemangi (Ocimmum basilicum forma citratum) terhadap perkembangan larva lalat rumah (Musca domestica). Pada konsentrasi ekstrak kemangi perlakuan $(2,5 \%, 5 \%, 10 \%, 20 \%$ dan kontrol), dan hasilnya pada konsentrasi $20 \%$ dapat menjadi daya penolak (repellent) larva lalat rumah yang efektif.

Beberapa hasil penelitian ini dapat diketahui bahwa kemangi dan daun jeruk sebagai bioinsektisida sudah baik dalam mengendalikan perkembangan hidup larva lalat dan jangkrik. Berdasarkan fakta-fakta di atas perlu dilakukan penelitian lebih lanjut tentang bagaimana pengaruh ekstrak daun kemangi (Ocimmum sanctum) sebagai bioinsektisida nabati terhadap repelan lalat rumah (Musca domestica). Maka peneliti tertarik untuk melakukan penelitian yang berjudul Pemanfaatan ekstrak daun kemangi (Ocimum sanctum) sebagai repelan lalat rumah (Musca domestica)."

Tujuan penelitian mengetahui kemampuan ekstrak daun kemangi (Ocimum sanctum) dengan dosis $0 \%, 20 \%, 30 \%$, dan $40 \%$ sebagai repelan lalat rumah (musca domestika) dalam waktu pengamatan 5 menit, 10 menit dan 15 menit.

\section{METODE}

Penelitian eksperimental ini menggunakan pola faktorial, terdiri dari 2 faktor yaitu faktor pertama ekstrak daun kemangi, F1=ekstrak daun kemangi $0 \%, \mathrm{~F} 2=$ ekstrak daun kemangi $20 \%$, $\mathrm{F} 3=$ ekstrak daun kemangi $30 \%$, dan F4=ekstrak daun kemangi $40 \%$. Faktor kedua waktu pengamatan repelan lalat rumah, $\mathrm{A} 1=$ waktu pengamatan 5 menit, $\mathrm{A} 2=$ waktu pengamatan 10 menit, A3=waktu pengamatan 15 menit. Penelitian ini menggunakan 4 perlakuan dan setiap perlakuan menggunakan 30 ekor lalat. Setiap perlakuan ini menggunakan 3 kali pengulangan dan setiap pengulangan menggunakan 30 ekor lalat, sehingga jumlah lalat rumah keseluruhan untuk menjadi sampel yaitu 360 ekor lalat. Analisis data hasil uji ekstrak daun kemangi dilakukan dengan cara membandingkan setiap hasil pengukuran, yaitu dosis $0 \%, 20 \%$, $30 \%$ dan $40 \%$ terhadap daya tolak/repelan lalat rumah Kemudian data diolah menggunakan analisis deskriptif kuantitatif kemudian dilakukan analisis varian dua jalur (two way anova). Penelitian dilakukan pada bulan Maret-Nopember 2018 di laboratorium Jurusan Kesehatan 
Lingkungan, Politeknik Kesehatan Tanjung Karang Lampung.

Bahan yang digunakan dalam penelitian ini antara lain: triplek, kayu ukuran $3 \times 3 \mathrm{~cm}$, kawat kasa/kain strimin, paku, kain katun, larutan gula, dan lalat rumah. Alat yang digunakan adalah botol semprot, kandang lalat, alat penghancur (blender) daun kemangi, pisau, kain kasa, form tabel pengamatan, stopwatch dan alat tulis. Botol semprot, pipet volume, dan labu takar.

Pembuatan ekstrak daun kemangi Sebanyak 500gr daun kemangi kemudian iris-iris $\pm 2 \mathrm{~cm}$, lalu dijemur sampai kering. Setelah kering dihancurkan sampai menjadi bubuk dengan blender, kemudian bubuk daun kemangi seberat 100gram dicampur etanol sebanyak $1500 \mathrm{ml}$ direndam selama 24 jam. Setelah direndam kemudian diambil air bagian atas dari rendaman bubuk daun kemangi dan etanol tersebut, kemudian air bagian atas dari rendaman bubuk daun kemangi dan etanol tersebut diuapkan dengan oven selama \pm 4 jam sehingga alkohol menguap, dan cairan yang masih ada sebagai ekstrak daun kemangi yang dosis $100 \%$. Untuk membuat dosis 20\%, maka ambil 20ml ekstrak daun kemangi dicampur dengan air sebanyak $100 \mathrm{ml}$, dan untuk membuat dosis 30\% ekstrak daun kemangi, maka ambil 30ml ekstrak daun kemangi dicampur dengan air sebanyak $100 \mathrm{ml}$, serta untuk membuat dosis $40 \%$ ekstrak daun kemangi, maka ambil 40ml ekstrak daun kemangi dicampur dengan air sebanyak $100 \mathrm{ml}$.

Pengamatan dilakukan dengan cara menyiapkan 4 botol semprot yang akan digunakan untuk spraying. masukan ekstrak daun kemangi kedalam botol semprot sesuai sesuai dosis yang sudah ditetapkan yaitu 0\%. 20\%, $30 \%$, dan $40 \%$. Lalat yang digunakan untuk penelitian ini yaitu lalat rumah (musca domestica) dewasa yang didapat dari penangkapan di pasar tradisional Natar dan disamping workshop Jurusan Kesehatan Lingkungan. Pada saat target lalat sudah ditemukan sedang istirahat pada media hinggapnya, Setelah perangkap siap pasang, maka perangkap diletakkan di tempat-tempat yang potensial terdapat lalat rumah. Siapkan umpan cumi-cumi dan udang untuk menarik lalat hinggap, kemudiaan beri makanan (tetesan air gula) untuk lalat agar tetap bergerak aktif/tetap hidup. Siapkan botol semprot yang telah terisi larutan ekstrak daun kemangi, kemudian masukkan lalat kedalam kotak kayu yang akan di uji kemudian semprotkan sebanyak 5 kali ekstrak daun kemangi pada umpan. Masukkan lalat dikotak kayu ke 1 yang sudah diisi umpan tersebut dengan dosis ekstrak daun kemangi $0 \%$, kotak 2 dengan dosis ekstrak daun kemangi 20\%, kotak ke 3 dengan dosis ekstrak daun kemangi $30 \%$, dan kotak ke 4 dengan dosis ekstrak daun kemangi $40 \%$. Untuk setiap kotak kayu dilakukan pengamatan selama 5 menit, 10 menit dan 15 menit dan diamati lalat rumah yang mendekati umpan dan berapa lama hinggap lalat rumah di umpan. Dilakukan perlakuan yang sama untuk 3 kali pengulangan.

Penelitian ini telah mendapat keterangan kelaikan etik (ethical clearance) dari Komisi Etik Penelitian Kesehatan Politeknik Kesehatan Tanjung Karang Nomor 218/EC/KEPTJK/VII/2018.

\section{HASIL}

Tabel 1. Hasil Pengamatan Organoleptik dan Homogenitas Ekstrak Daun Kemangi

\begin{tabular}{cllll}
\hline Dosis & Warna & Aroma & Tekstur & Homogenitas \\
\hline $20 \%$ & Hijau & $\begin{array}{l}\text { Khas daun } \\
\text { kemangi } \\
\text { menyengat }\end{array}$ & $\begin{array}{l}\text { Cair } \\
\text { (kental) }\end{array}$ & Homogen \\
$30 \%$ & Hijau & $\begin{array}{l}\text { Khas daun } \\
\text { kemangi } \\
\text { menyengat } \\
\text { Khas daun } \\
\text { kemangi } \\
\text { menyengat }\end{array}$ & $\begin{array}{l}\text { Cair } \\
\text { (kental) }\end{array}$ & Homogen \\
& Hijau & Homogen & \\
\hline
\end{tabular}

Hasil pengamatan uji organoleptik, dan homogenitas ekstrak daun kemangi pada tabel 1 menunjukkan bahwa hasil ekstrak daun kemangi untuk semua warna berwarna hijau, tetapi untuk dosis $20 \%$ ekstrak daun kemangi warna hijau kurang pekat dibandingkan dosis ekstrak daun kemangi 30\%, dan dosis ekstrak daun kemangi $30 \%$, warna hijau kurang pekat lagi dibandingkan dengan dosis ekstrak daun kemangi $40 \%$, sehingga semakin tinggi dosis ekstrak daun kemangi maka warna hijau semakin pekat. Homogenitas dari semua dosis ekstrak daun kemangi hampir sama, hanya untuk tekstur terlihat lebih kental untuk dosis ekstrak daun kemangi lebih tinggi.

Bau/aroma daun kemangi menyengat karena komposisi daun kemangi mengandung minyak atsiri dan eugenol yang membuat aroma lebih menyengat (Hartati, 2012). Dosis 20\% ekstrak daun kemangi bau/aroma kurang menyengat dibandingkan dengan dosis ekstrak daun kemangi $30 \%$, demikian juga untuk ekstrak daun kemangi 30\% aroma kurang menyengat dibandingkan dengan dosis ekstrak daun kemangi $40 \%$, jadi semakin tinggi dosis ekstrak daun kemangi maka bau/aroma lebih menyengat. Hasil pengukuran derajat keasaman $(\mathrm{pH})$ pada dosis $20 \%, 30 \%$ dan $40 \%$ ekstrak daun kemangi 
dengan menggunakan $\mathrm{pH}$ meter menunjukkan hasil rerata $\mathrm{pH}$ 5,6-6.

Tabel 2. Distribusi Daya Tolak/ Repelan Lalat Rumah (Musca domestica) terhadap Ekstrak Daun Kemangi

\begin{tabular}{|c|c|c|c|c|c|}
\hline \multirow{2}{*}{$\begin{array}{c}\text { Dosis } \\
(\%)\end{array}$} & \multirow{3}{*}{$\begin{array}{c}\text { Per- } \\
\text { lakuan }\end{array}$} & \multirow{3}{*}{$\begin{array}{c}\text { Jlh } \\
\text { lalat } \\
\text { (Ekor) }\end{array}$} & \multirow{2}{*}{\multicolumn{3}{|c|}{$\begin{array}{c}\text { Daya Tolak/ Repelan } \\
\text { Lalat Rumah }\end{array}$}} \\
\hline & & & & & \\
\hline \multirow{6}{*}{$0 \%$} & & & 5 & 10 & 15 \\
\hline & I & 30 & 25 & 26 & 27 \\
\hline & II & 30 & 26 & 25 & 27 \\
\hline & III & 30 & 25 & 26 & 27 \\
\hline & Rerata & & 25,3 & 25,6 & 27 \\
\hline & $\%$ & & 84,3 & 85,3 & 90,0 \\
\hline \multirow{5}{*}{$20 \%$} & I & 30 & 27 & 26 & 27 \\
\hline & II & 30 & 27 & 27 & 28 \\
\hline & III & 30 & 26 & 26 & 27 \\
\hline & Rerata & & 28,6 & 26,6 & 26.3 \\
\hline & $\%$ & & 88,6 & 87,6 & 91,0 \\
\hline \multirow{5}{*}{$30 \%$} & I & 30 & 30 & 28 & 29 \\
\hline & II & 30 & 30 & 29 & 30 \\
\hline & III & 30 & 30 & 29 & 30 \\
\hline & Rerata & & 28,6 & 29,6 & 30 \\
\hline & $\%$ & & 95.3 & 98,60 & 100 \\
\hline \multirow{5}{*}{$40 \%$} & I & 30 & 28 & 30 & 29 \\
\hline & II & 30 & 29 & 30 & 29 \\
\hline & III & 30 & 29 & 30 & 29 \\
\hline & Rerata & & 28,6 & 30 & 29 \\
\hline & $\%$ & & 95,5 & 100 & 96,6 \\
\hline
\end{tabular}

Pada tabel 2 menunjukkan bahwa daya tolak/repelan lalat rumah (Musca domestica) terhadap ekstrak daun kemangi, dengan 3 kali pengulangan, pada dosis ekstrak daun kemangi $0 \%$ dengan waktu pengamatan 5 menit, daya tolak/repelan lalat rumah yang terendah/yang hinggap lalat rumah sebanyak 5 ekor. Kemudian pada dosis 30\% dengan waktu pengamatan 10 menit dan 15 menit dan dengan dosis 40\% dengan waktu pengamatan 10 menit daya tolak/repelan lalat rumah yang tertinggi/lalat rumah yang hinggap tidak ada (0 ekor) pada media repelan.

\section{Dosis 0\% Ekstrak Daun Kemangi terhadap Repelan Lalat Rumah (Musca Domestica)}

Pada Grafik 1. Ekstrak Daun Kemangi dengan dosis $0 \%$, digunakan sebagai kontrol (tanpa bioinsektisida) dalam penelitian ini, sehingga daya tolak/repelan lalat rumah pada waktu pengamatan 5 menit, 10 menit dan 15 menit berturut-turut yaitu $84,3 \%, 85,3 \%$ dan $90 \%$. Hasil uji statistik diperoleh nilai sig $0,011<0,05$. Dengan demikian $\mathrm{H}_{0}$ ditolak, sehingga terdapat perbedaan kemampuan penggunaan ekstrak daun kemangi terhadap daya tolak/repelan lalat rumah yang signifikan.

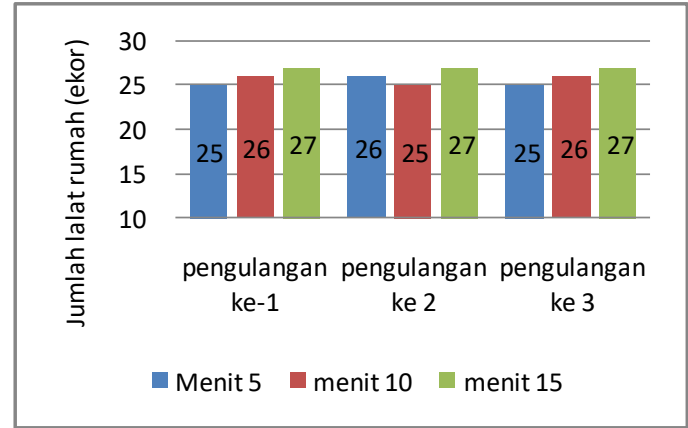

Grafik 1. Daya Repelan Lalat Rumah terhadap Ekstrak Daun Kemangi Dosis 0\%

\section{Dosis 20\% Ekstrak Daun Kemangi terhadap Repelan Lalat Rumah (Musca Domestica)}

Pada Grafik 2 Dosis $20 \%$ ini digunakan sebagai awal pemberian bioinsektisida dalam penelitian ini. Pada dosis ini daya tolak/repelan lalat rumah dengan waktu pengamatan 5 menit, 10 menit dan 15 menit berturut-turut yaitu $88,6 \%, 87,6 \%$ dan 91\%. Hasil uji statistik diperoleh bahwa nilai sig 0,178>0,05. Dengan demikian $\mathrm{H}_{0}$ diterima, sehingga tidak terdapat perbedaan kemampuan penggunaan ekstrak daun kemangi terhadap daya tolak/repelan lalat rumah yang signifikan.

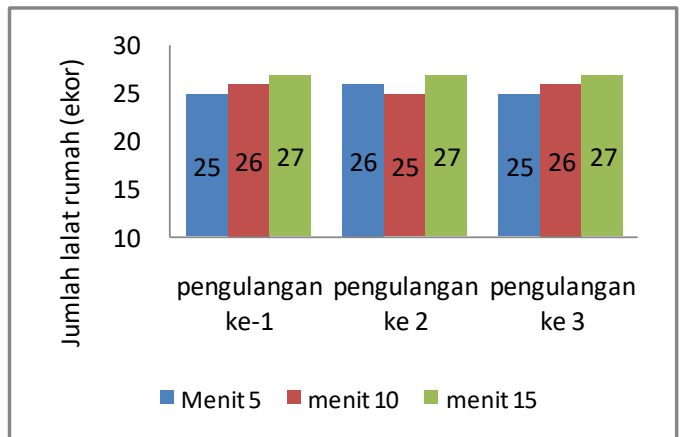

Grafik 2. Daya Repelan Lalat Rumah terhadap Ekstrak Daun Kemangi Dosis 20\%

\section{Dosis 30\% Ekstrak Daun Kemangi terhadap Repelan Lalat Rumah (Musca Domestica)}

Pada Grafik 3 dosis ekstrak daun kemangi $30 \%$ daya tolak/repelan lalat rumah dengan waktu pengamatan 5 menit, 10 menit dan 15 menit berturut-turut yaitu $95,3 \%, 98,6 \%$ dan $100 \%$. Hasil uji statistik diperoleh bahwa nilai sig $0,031<0,05$. Dengan demikian $\mathrm{H}_{0}$ ditolak, sehingga terdapat perbedaan kemampuan penggunaan ekstrak daun kemangi terhadap daya tolak/repelan lalat rumah yang signifikan. 


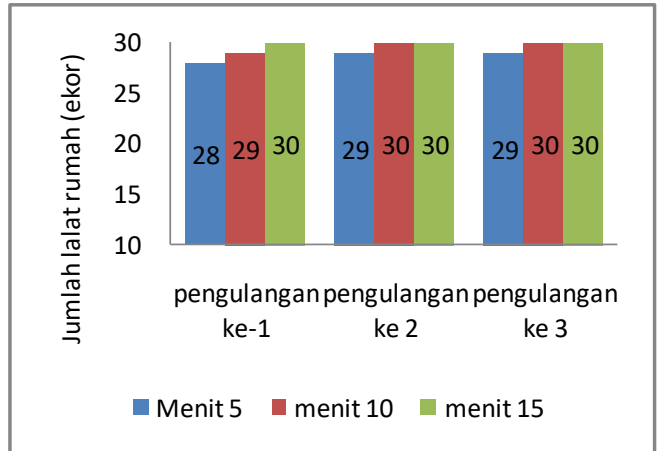

\section{Grafik 3. Daya Repelan Lalat Rumah terhadap Ekstrak Daun Kemangi Dosis 30\%}

\section{Dosis 40\% Ekstrak Daun Kemangi terhadap Repelan Lalat Rumah (Musca Domestica)}

Pada Grafik 4 dosis ekstrak daun kemangi $40 \%$ daya tolak/repelan lalat rumah dengan waktu pengamatan 5 menit, 10 menit dan 15 menit berturut-turut yaitu $95,5 \%, 100 \%$ dan $96,6 \%$. Hasil uji statistik diperoleh bahwa nilai sig $0,007<0,05$. Dengan demikian $\mathrm{H}_{0}$ ditolak, sehingga terdapat perbedaan kemampuan penggunaan ekstrak daun kemangi terhadap daya tolak/repelan lalat rumah yang signifikan.

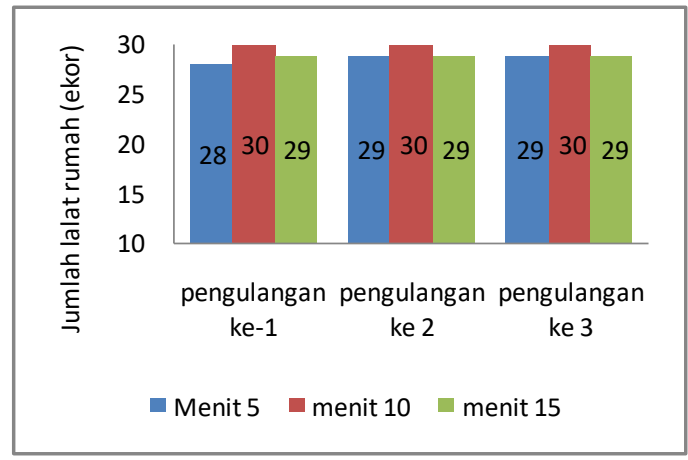

\section{Grafik 4. Daya Repelan Lalat Rumah terhadap Ekstrak Daun Kemangi Dosis $40 \%$}

\section{Daya Tolak/Repelan Lalat Rumah (Musca domestica) terhadap Dosis Ekstrak Daun Kemangi 0\%, 20\%, 30\% dan $40 \%$}

Pada Grafik 5 Daya tolak/repelan lalat rumah (Musca domestica) terhadap dosis ekstrak daun kemangi yang terendah dengan dosis $20 \%$ diperoleh nilai sig $0,178>0,05$ dan nilai yang tertinggi diperoleh dengan dosis $40 \%$, dengan nilai sig $0,007<0,05$, sehingga kemampuan penggunaan ekstrak daun kemangi memberi pengaruh terhadap daya tolak/repelan lalat rumah.

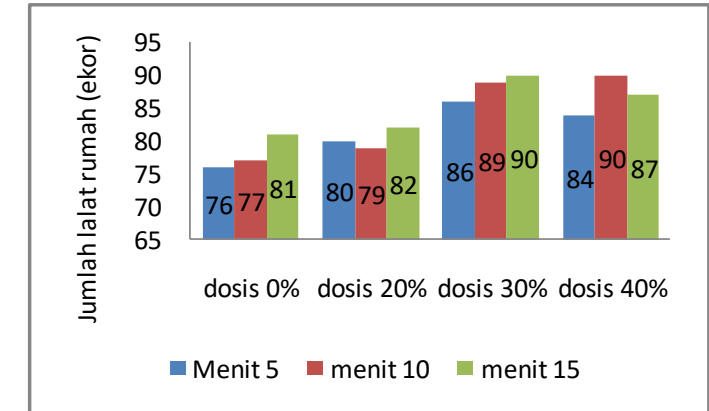

Grafik 5. Daya Repelan Lalat Rumah terhadap Ekstrak Daun Kemangi

Pengujian organoleptik meliputi warna, aroma dan tekstur yang diamati secara visual terhadap ketiga dosis menunjukkan warna hijau pada ekstrak daun kemangi. Hal ini disebabkan karena pengaruhi warna dari daun kemangi sebagai bahan aktif. Pada ekstrak daun kemangi diberi ethanol sebagai pelarut zat aktif yang ada pada daun kemangi. Ketiga dosis ekstrak daun kemangi, bau paling tajam tercium pada ekstrak daun kemangi dengan dosis $40 \%$. Tekstur ekstrak daun kemangi ketiga dosis menunjukkan kekentalan, yang dipengaruhi dari kandungan minyak atsiri yang terkandung secara alamiah pada daun kemangi (Hartati, 2012).

Homogenitas ketiga dosis ekstrak daun kemangi memenuhi syarat apabila akan diaplikasikan sebagai penolak lalat rumah. Kemudian derajat keasaman ketiga dosis ekstrak daun kemangi menunjukkan $\mathrm{pH}$ cenderung asam tapi masih mendekati netral $\mathrm{pH}(5,6-6)$, sehingga masih layak dijadikan sebagai daya tolak repelan lalat rumah. Jumlah daya tolak/repelan lalat rumah (musca domestica) pada dosis ekstrak daun kemangi $30 \%$ dan $40 \%$ yang lebih tinggi terhadap peningkatan daya repelan lalat rumah.

\section{PEMBAHASAN}

Hasil Uji Organoleptik, dan Homogenitas Ekstrak Daun Kemangi

Pengujian organoleptik meliputi warna, aroma dan tekstur yang diamati secara visual terhadap ketiga dosis menunjukkan warna hijau pada ekstrak daun kemangi. Hal ini disebabkan karena pengaruhi warna dari daun kemangi sebagai bahan aktif. Pada ekstrak daun kemangi diberi ethanol sebagai pelarut zat aktif yang ada pada daun kemangi. Ketiga dosis ekstrak daun kemangi, bau paling tajam tercium pada ekstrak daun kemangi dengan dosis $40 \%$. Tekstur ekstrak daun kemangi ketiga dosis menunjukkan kekentalan, yang dipengaruhi dari kandungan 
minyak atsiri yang terkandung secara alamiah pada daun kemangi (Hartati, 2012).

Homogenitas ketiga dosis ekstrak daun kemangi memenuhi syarat apabila akan diaplikasikan sebagai penolak lalat rumah. Kemudian derajat keasaman ketiga dosis ekstrak daun kemangi menunjukkan $\mathrm{pH}$ cenderung asam tapi masih mendekati netral $\mathrm{pH}(5,6-6)$, sehingga masih layak dijadikan sebagai daya tolak repelan lalat rumah. Jumlah daya tolak/repelan lalat rumah (musca domestica) pada dosis ekstrak daun kemangi $30 \%$ dan $40 \%$ yang lebih tinggi terhadap peningkatan daya repelan lalat rumah.

\section{Kemampuan Ekstrak Daun Kemangi Dosis 0\% terhadap Repelan Lalat Rumah (Musca Domestica)}

Pada daun kemangi terdapat minyak atsiri yang mengandung senyawa yang memiliki bau menyengat, salah satunya yaitu senyawa geraniol. "Geraniol merupakan salah satu senyawa kimia bahan alam yang efektif untuk mengusir serangga" (Wijayani, dkk., 2014). Oleh sebab itu walaupun dalam perlakuan tanpa memberikan ekstrak daun kemangi kemungkinan bau yang menyengat berasal dari kotak lalat rumah yang diberi ekstrak daun kemangi sangat berdekatan $( \pm 30 \mathrm{~cm})$ sehingga kepekaan penciuman dari lalat rumah yang senang hinggap pada bau busuk seperti kotoran ternak, kotoran manusia dan bau makanan yang merangsang seperti ikan, cumi, udang dan lain-lain juga dapat mempengaruhi.

\section{Kemampuan Ekstrak Daun Kemangi Dosis 20\% Terhadap Repelan Lalat Rumah (Musca Domestica)}

Kemampuan ekstrak daun kemangi dosis $20 \%$ berbeda dengan kedua dosis ekstrak daun kemangi lainnya dan kontrol. Hasil uji statistik nilai sig $0,178>0,005$ sehingga tidak terdapat perbedaan yang signifikan. Atau tingkat daya tolak lalat rumah yang paling rendah terhadap ekstrak daun kemangi walaupun secara deskriptif jumlah lalat rumah yang terbang sebanyak 26-28 ekor atau 2-4 ekor lalat rumah yang hinggap.

Hal ini membuktikan bahwa zat bioaktif dalam daun kemangi yang dapat berfungsi sebagai racun pernafasan. Kandungan eugenol dalam daun kemangi merupakan senyawa fenol yang memiliki gugus alkohol sehingga dapat melemahkan dan mengganggu sistem syaraf, sehingga jika lalat rumah mendekat dapat mengakibatkan kelemahan syaraf lalat rumah. Lalat rumah yang mencium bau dari ekstrak daun kemangi yang menyebabkan lalat tersebut menghindar, karena racun pernapasan bekerja lewat saluran pernapasan. Kebanyakan racun pernapasan berupa gas (Djojosumarto, 2000). Racun pernapasan adalah insektisida yang mematikan serangga karena mengganggu kerja organ pernapasan (misalnya menghentikan kerja otot yang mengatur pernapasan) sehingga mati akibat tidak bisa bernapas. Biasanya insektisida jenis ini digunakan untuk serangga yang tidak tergantung pada bentuk mulutnya (Djojosumarto, 2005).

\section{Kemampuan Ekstrak Daun Kemangi Dosis 30\% terhadap Repelan Lalat Rumah (Musca Domestica)}

Dosis ekstrak daun kemangi 30\% sebagai racun pernapasan, lalat rumah yang mencium bau dari ekstrak daun kemangi yang menyebabkan lalat rumah menghindar, dan yang hinggap pada umpan yang sudah disediakan hanya sebanyak 2 ekor. Berdasarkan pengujian insektisida nabati, daya tolak lalat rumah (Musca domestica), paling tinggi terdapat pada perlakuan dosis ekstrak daun kemangi 30\% dan pada waktu pengamatan 15 menit, tidak ada lalat rumah yang hinggap.

Daya tolak/repelan lalat rumah terhadap ekstrak daun kemangi yang tinggi, dikarenakan pada bahan insektisdia nabati memiliki kandungan senyawa sekunder yang dapat mengganggu syaraf lalat rumah, Senyawa metabolisme sekunder pada tumbuhan diproduksi oleh tumbuhan itu sendiri sebagai perlindungan terhadap mikroorganisme dan predator seperti serangga. Ekstrak daun kemangi mengandung eugenol dan kavicol. Kavicol merupakan derifat dari senyawa fenol, yang memberikan aroma khas pada daun kemangi, yang dapat digunakan sebagai antibakteri (Koensoemardiyah, 2010).

Kemampuan Ekstrak Daun Kemangi Dosis 40\% terhadap Repelan Lalat Rumah (Musca Domestica)

Dosis ekstrak daun kemangi $40 \%$ sebagai racun pernapasan pada lalat rumah, daun kemangi mengandung flavonoid dapat menghambat pertumbuhan dan bekerja sebagai inhibitor pernafasan, proses kerja flavonoid pada tubuh lalat rumah apabila melakukan kontak dengan kulit maka akan merusak mukosa kulit, sedangkan kandungan senyawa tanin dapat dijadikan sebagai insektisida karena memiliki fungsi sebagai racun kontak pada serangga sehingga mengakibatkan aktifnya 
enzim lisis sel karena enzim proteolitik pada sel tubuh lalat rumah. Tannin dapat menghambat masuknya zat makanan ke dalam tubuh serangga, sehingga menyebabkan gangguan metabolisme dan fisiologis sel, dan menyebabkan kerusakan pada sel. Penelitian ini sejalan dengan penelitian Ridhwan (2016) bahwa salah satu tumbuhan yang digunakan sebagai pestisida nabati adalah tanaman kemangi tetapi untuk membunuh larva nyamuk (Anopheles aconitus) sedangkan menurut Dwi Anugraheni (2018) insektisida nabati tanaman kemangu dan ekstrak daun sirih dengan berbagai jenis pelarut dan tingkat konsentrasi yang berbeda berpengaruh terhadap mortalitas lalat buah.

Flavonoid merupakan senyawa turunan fenol alam terbesar yang ditemukan pada semua tumbuhan berpembuluh. Flavonoid merupakan senyawa yang bersifat racun terhadap jenis serangga. Dalam pembuatan insektisida nabati ini, pada daun kemangi mengandung senyawa diantaranya adalah metil eugenol. Adanya kandungan metil eugenol pada kemangi ini dapat dijadikan sebagai repelan alami untuk pengendalian lalat rumah. Menurut Naria (2005), pengendalian lalat rumah menggunakan repelan ini sangat baik sebagai insektisida nabati pada rumah tangga, sehingga ketika lalat rumah tercium aroma dari repelan dapat menghindar karena pengaruh bau/aroma yang menyengat. Berdasarkan hasil penelitian menunjukan bahwa insektisida nabati ekstrak daun kemangi dengan jenis pelarut etanol $90 \%$ dan tingkat dosis yang berbeda berpengaruh terhadap daya repelan lalat rumah.

\section{Kelebihan dan Kelemahan Pestisida Berbasis Minyak Atsiri}

Kelebihan pestisida berbasis minyak atsiri adalah aktivitas biologinya yang berspektrum sangat luas, tidak toksik, sistemik, kompatibel, mudah terdegradasi, dan lebih aman dibanding dengan bahan kimia sintetik. Pestisida berbahan minyak atsiri juga aman bagi lingkungan, karena bersifat tidak persisten. Hal ini karena minyak atsiri mudah diurai secara alami, sehingga tidak tahan lama di air, udara, di dalam tanah, dan tubuh mamalia. Minyak atsiri juga efektif terhadap organisme sasaran, kompatibel dengan cara pengendalian lain, aman dan tidak toksik terhadap organisme bukan sasaran serta lingkungan dan kesehatan manusia, sehingga minyak atsiri mempunyai potensi yang sangat besar untuk dikembangkan sebagai pestisida nabati secara komersial (Hartati, 2012).

Adapun kelemahan-kelemahan dari pestisida berbasis minyak atsiri adalah berhubungan dengan sifat-sifat dari minyak atsiri sendiri yang volatil dan tidak stabil atau tidak tahan terhadap sinar matahari. sebagai contoh, sinamaldehid bersifat tidak stabil dan akan terurai mdnjadi banaldehid pada suhu $60^{\circ} \mathrm{C}$. Namun ketika dikombinasi dengan eugenol atau cinamon minyak daun, maka sinamaldehid akan stabil sampai suhu $200^{\circ} \mathrm{C}$ selama lebih dari 30 menit.

Keefektifan pestisida minyak atsiri umumnya lebih rendah dibandingkan dengan pestisida kimia sintetik dan kerjanya lebih lambat. Aktivitas biologi yang ditunjukkan oleh minyak atsiri dapat bersifat menolak, menarik, racun kontak racun pernafasan, mengurangi nafsu makan, menghambat peletakkan telur dan menghambat pertumbuhan (Dubey, 2010).

Oleh karena itu, didalam formula pestisida berbahan aktif minyak atsiri selalu ditambahkan senyawa kimia lain yang sifatnya meningkatkan stabilitas bahan aktifnya.

\section{SIMPULAN}

Daun kemangi mengandung minyak atsiri dengan bahan aktif eugenol dan sineol yang mempunyai potensi sebagai bioinsektisida repelan untuk lalat rumah (Musca domestica). Kemampuan ekstrak daun kemangi dosis $0 \%$ dan nilai sig $0,011<0,05$, ada perbedaan yang signifikan terhadap daya tolak/repelan lalat rumah. Kemampuan ekstrak daun kemangi dosis $20 \%$ dan nilai sig $0,178>0,05$, tidak ada perbedaaan yang signifikan terhadap daya tolak/repelan lalat rumah. Kemampuan ekstrak daun kemangi dosis $30 \%$ dan nilai sig $0,031<0,05$, ada perbedaan yang signifikan terhadap daya tolak/repelan lalat rumah. Kemampuan ekstrak daun kemangi dosis $40 \%$ dan hasil uji sig $0,007<0,05$, ada perbedaan yang signifikan terhadap daya tolak/repelan lalat rumah. 


\section{DAFTAR PUSTAKA}

Ariyani, D. D., \& Raharjo, E. I. (2016). Pengaruh Ekstrak Daun Kemangi (Ocimum basilicum L) terhadap Daya Tetas Telur Ikan Lele Dumbo (Clarias gariepinus) yang Diinfeksi Jamur Saprolegnia sp. [Artikel Ilmiah]. Pontianak: Fakultas perikanan dan ilmu kelautan, Universitas Muhammadiyah Pontianak. http://repository.unmuhpnk.ac.id/id/eprint/ 81.

Djojosumarto, P. (2000). Teknik Aplikasi Pestisida Pertanian. Yogyakarta: Kanisius.

Dubey, N.K., Shukla, A.K. PS and Pracash, B. (2010). Prospects of botanical pesticides in sustainable agriculture. Current Science, 4(98):479-480.

Dwi Anugraheni, D., \& Asngad, A. (2018). Pengaruh Insektisida Nabati Ekstrak Tanaman Kemangi (Ocimum basilicum) dan Daun Sirih Terhadap Mortalitas Lalat Buah (Bactrocera sp.) Seminar Nasional Pendidikan Biologi dan Saintek III.

Gunandini, D. J., \& Kardinan, A. (2008). Pengaruh ekstrak kemangi (Ocimum basilicum forma citratum) terhadap perkembangan lalat rumah (Musca domestica)(L.). Jurnal Entomologi Indonesia, 5(1), 36.

Hartati SY. (2012). Prospek Pengembangan Minyak Atsiri sebagai Pestisida Nabati. Perspektif, Vol.11, No.1/Juni 2012. Balai Penelitian Tanaman Rempah dan Obat. Bogor.
Kathiraysen. (2011). Uji Potensi Ekstrak Biji Pucung (Pangium edule) sebagai Insektisida Terhadap Lalat Musca domestica. Jurnal Fakultas Kedokteran. Universitas Brawijaya. Malang. http://old.fk.ub.ac.id Diakses 16 maret 2017.

Koensoemardiyah. (2010). A to Z Minyak Atsiri untuk Industri Makanan, kosmetik, dan Aromaterapi. Jakarta: Lilly Publisher.

Mardhotillah, S. (2012). Pengaruh Aroma Umpan dan Warna Kertas Perangkap terhadap Jumlah Lalat yang Terperangkap. Jurnal Litbang, 2(2).

Naria. (2005). Insektisida Nabati untuk Rumah Tangga. Info Kesehatan Masyarakat. Fakultas Kesehatan Masyarakat. Universitas Sumatera Utara. Medan. http://repository.usu.ac.id

Ridhwan M, \& Isharyanto. (2016). Potensi Kemangi Sebagai Pestisida Nabati. Serambi Saintia, Vol IV, No.1. Universitas Serambi Mekkah. Aceh.

Wijayani, L. A., \& Isti'anah, S. (2014). Efek Larvisidal Ekstrak Etanol Daun Kemangi (Ocimumsanctum Linn) Terhadap Larva Instar III Culexquinquefasciatus. Biomedika, 6(2).

Yuriatni. (2011). Keanekaragaman Lalat (Cyclorrapha : Diptera) dan Parasit Usus yang Dibawanya di Kabupaten dan Kota Solok Sumatra barat. [Tesis]. Padang: Program Pasca Sarjana, Universitas Andalas. 